\title{
Competitive advantage of carbon efficient supply chain in manufacturing industry
}

\author{
Obafemi O. Olatunji ${ }^{\text {a, }}$, Olayinka O. Ayo ${ }^{\text {b }}$, Stephen Akinlabi ${ }^{\text {c, d }}$, Felix Ishola ${ }^{\text {d, }}{ }^{* *}$, \\ Nkosinathi Madushele ${ }^{a}$, Paul A. Adedeji ${ }^{a}$ \\ a Department of Mechanical Engineering Science, University of Johannesburg, South Africa \\ ${ }^{\mathrm{b}}$ Department of Electrical and Information Engineering, Covenant University, Nigeria \\ ${ }^{c}$ Department of Mechanical Engineering, Covenant University, Nigeria \\ d Department of Mechanical \& Industrial Engineering Technology, University of Johannesburg, South Africa
}

\section{A R T I C L E I N F O}

\section{Article history:}

Received 13 March 2019

Received in revised form 24 June 2019

Accepted 5 August 2019

Available online 5 August 2019

Handling Editor: Yutao Wang

\section{Keywords:}

Competitive advantage

Carbon efficiency

Sustainable production

Strategic implementation

Supply chain

\begin{abstract}
A B S T R A C T
The competitiveness of the manufacturing industry is fundamentally intertwined between sustainable production and carbon efficiency in the supply chain. There is a growing level of alertness to environmental protection vis-a-vis emission control and the climate change. Apart from the cost reduction, network optimization, profit maximization, risk mitigation, and value-added services, the modern manufacturing has added carbon footprint reduction to their performance indices. Therefore, the focus is changing to green manufacturing and carbon efficient supply chain, which is intended to improve their production and product consumption as a result of competitive advantage. However, mitigating the climate change demands a more fundamental shift in the way the manufacturing industry delivers products and services to the end users. This research investigates how the competitive advantage of a carbon efficient supply chain can be sustained. Some automobile manufacturing company in the United Kingdom were considered as the case study. Data were sourced through interview, survey questions and from the existing literature. The cross-case synthesis was applied to draw comparison among different companies used as the case study. Influencing drivers and barriers associated with the automobile manufacturing supply chain were identified. The investigation revealed that consumers are the major driver of competitive advantage in manufacturing, with the competition now moved to supply chain which is associated with a different level of product consumption. The impact of other existing strategic factors was also identified. A flow chart for the strategic implementation of carbon efficiency practices along the supply chain was developed. In overall, the study revealed the need for the implementation of carbon reduction strategies in business development.
\end{abstract}

() 2019 Elsevier Ltd. All rights reserved.

\section{Introduction}

Mitigation of carbon footprint is a humongous task for both researchers and professionals. Many countries have enacted legislation and policy which are inclined to curbing carbon emission (Tiwari et al., 2015; Centobelli et al., 2018). In the recent years, closed looped carbon efficient supply chain has been revolutionized

\footnotetext{
** Corresponding author.

* Corresponding author.

E-mail addresses: tunjifemi@gmail.com (O.O. Olatunji), olayinka.ayo@ covenantuniversity.edu.ng (O.O. Ayo), stephenakinlabi@gmail.com (S. Akinlabi), felix.ishola@covenantuniversity.edu.ng (F. Ishola), nmadushele@uj.ac.za (N. Madushele), pauladedeji2k5@gmail.com (P.A. Adedeji).
}

so much that it is the centre of attention of governmental laws and policy amidst the soaring consumer expectation (Talaei et al., 2016; Seman et al., 2012). Across the nations, different organization are undertaking initiatives to lessen their carbon footprint in response to the concerns of their customers. Carbon-efficient supply chain, SC is gaining traction in manufacturing supply chain management systems. This is due to the recent development and understanding of climate change which have placed the onus of the design and operation of the highly competitive supply chain network on the environmentalist. However, mitigating the climate change, require a more fundamental approach to product and service delivery to the end consumers. So, in order to achieve the best manufacturing practice which take cognizance of climate change, there is a need for an integrated approach to environmental management and 
manufacturing operations (Wilkerson, 2005). There are several green or carbon efficient supply chain practices, these include; Green manufacturing, green logistics, green procurement, green marketing, green general management, and green finance (Smith and Perks, 2010; Silins, 2009; Garen, 2009). Also, several critical factors which are incidental to the successful implementation of green supply chain strategies has been identified by different authors. For instance, Malviya et al. (2018) identified five critical factors which are: green design and development, green procurement, green manufacturing, green marketing and green management system; Chatterjee et al. (2018) identified five factors: green design, green purchasing, green production, green warehousing, and green transportation; Sun and Zhu (2018) identified six factors: green procurement, green manufacturing, green logistics, green service, green benefits, and green growth; Agi and Nishant (2017) identified four factors in the analysis of green supply chain management (GCSM); market pressure, associated stakeholder pressure, and inter and intra organizational dynamics. A review of these factors shows similarities and interdependence which affects the green practices across various organization, although the correlations are stronger among similar organization (Sellitto et al., 2019).

Since future product demands are linked to the manufacturing and consumption of goods and services which support sustainable development and the climate change mitigation (Hertwich and Peters, 2009), the recent emphasis of SC has transformed from cost reduction, network optimization to carbon emissions reduction, service level improvements, risk mitigation and value creation (Sundarakani et al., 2008). By engaging with their SC, manufacturing organization and others can minimize the risks from climate change, while spotting business opportunities and deepen relationships with key business allies (Dasaklis and Pappis, 2013). While some manufacturing organization have come to term with the reality of carbon emission, large proportion of organizations are still under the pressures to minimize the carbon emissions that emanate from their business activities because they have not realised the opportunity that abounds across their delivery process which is basically the SC. Many organizations see it as unnecessary, possibly because their customers are not requesting much from it, while some other organization still perceive the change to carbon efficient supply chain as costly and burdensome (Seman et al., 2012). In the year 2009, a survey carried out by South Africa poultry association, SAPA, showed that $40 \%$ of the reported companies were not subscribing to friendly environmental business strategies. Interestingly, the remaining $60 \%$ of the companies which employ carbon efficient supply chain indicated that they had a competitive advantage as noted in their profit margin and savings in purchases and production (AFRICA, 2009).

According to GHG protocol, carbon emission associated with an organization can be divided into three scopes namely; scope 1 , scope 2, scope 3 (Leeet al., 2013; Lee, 2011). In a recent survey conducted by CDP, with a focus on carbon efficiency, the supply chain management of 99 organization with almost 4800 suppliers was reported, 551 million tonnes of $\mathrm{CO}_{2}$ which is equivalent to US $\$ 14$ billion cost saving were reduced across the SC (ACTION(CDP), 2018).

The major driver of competitive advantage is the consumer whose impact is substantially predominant over other drivers, and competition has now shifted to supply chain basis. Literature is inundated with the researches on the benefits and prospects which can be derived from a supply chain with low carbon footprints (Malviya et al., 2018; Sun and Zhu, 2018; Sellitto et al., 2019; Lee, 2011; Petljak et al., 2018; Kusi-Sarpong et al., 2019; Jabbour et al., 2015), but strategies which can be applied to harness these benefits need to be further highlighted.

This research investigates how the competitive advantage of a carbon efficient supply chain can be maintained using two multinational automobile manufacturing companies, which are in the United Kingdom as a case study. The impact on the other existing strategic factors was also noted. The general goal of this research is to emphasize that a carbon efficient supply chain can be of competitive advantage. This is to add to the breadth of knowledge in supply chain management and give manufacturing organizations more incentives to improve their supply chain competitiveness while complying with the climate change policies.

\section{Materials and methods}

The approach applied in this study is a hybrid of induction and deduction (Fereday and Muir-Cochrane, 2006; Takefuji and Yamada, 2019; Goel et al., 2019; Vreys et al., 2019; Ambekar et al., 2019). Deductive research approach progresses from general perspective on the subject of investigation to more specific view of the situation while the inductive approach proceed from segmented theory to more universal theory regarding a specific investigation while also considering the environment of the event under investigation (Bell et al., 2018; Morse, 2003; Skillman et al., 2019). Saunders et al. (Saunders, 2011; Saunders et al., 2007), Walliman (2017), and Carlton and Perloff (2015) elucidated that deductive research approach are mostly used to test a theory while inductive are appropriate for theory formulation. Given the fact that there is limited generalization ability of a deductive based research approach, this method is best suited when there is vast amount of literatures while inductive method can be used for new research areas with limited literature (Goel et al., 2019; Saunders et al., 2007). Consequentially, this research applied a hybrid approach based on the deductive and inductive methods. The authors interpretation of acquired data and perspectives from literature were integrated to advance how competitive advantage can be sustained in a carbon efficient supply chain. As per deductive approach the theory of energy use and carbon emissions along supply chains, which is already established, was confirmed through literature survey, while the data acquired on carbon efficient supply chains and competitive advantage, through the integration of authors' interpretations, was used to set up theory on the sustainability of competitive advantage; hence the inductive approach. This research was carried out using the case study approach based on the research questions and the existing literature (Lee, 2011; Plassmann, 2018; Penz and Polsa, 2018; Lee and Cheong, 2011; Hua et al., 2011; Benjaafar et al., 2013), with a focus on the automobile manufacturing. A comparison was made with a public sector company to represent a less competitive environment. The cross-case synthesis was suitable for this research because of the different case study companies which are in different industrial sectors (Yin, 2009). This allowed for comparison of both industrial sectors to determine whether a general good practice model of implementing carbon efficiency in a supply chain could be developed. The information was collated and reordered; the comparison was made among the classified data for contextual analysis.

\subsection{Research sample}

The questionnaire survey method was employed with a focus on two major, and highly competitive automobile industry in the United Kingdom representing highly competitive environment and the less competitive environment was a company in the public sector in the same country. The automobile companies interviewed were anonymously represented by Greek letters; $y$ (gamma) and $\delta$ (delta) while the Public company was represented by $\mathrm{Z}$ (zeta). The respondents were carefully selected based on their job roles as related to supply chain and environmental management in the 
company as presented in Table 1 . Also, presented in Table 2 is a brief description of these companies.

\subsection{Measurement scale and reliability analysis}

To enhance the validity of this survey, procedures about the researches on multiple case study were followed (Yin, 2015; Voss, 2010). All the companies surveyed were called. The aim of the study was vividly explained to them, and the content of the questionnaire was explained, while the name and the job title of each respondent were noted before the mailing of the questionnaire. The respondents were allowed the maximum duration of two weeks to complete the questionnaire. A total of 21 respondent were received out of 100 email sent.

Six experts and scholars which are professionals in supply chain and carbon emission management were requested to modify the questionnaire in the first instance. Moreover, a pilot test was carried out with Damco Logistics, a third-party logistics company who does the measurement of carbon footprint. This placed them in a suitable position to answer most of the questions. It was electronically mailed randomly to supply chain managers in manufacturing company, $\mathrm{R} \& \mathrm{D}$, or environmental protection officer of different companies. They were requested to complete the questionnaire and spot the ambiguities in meaning and terms. With this procedure, the reliability was ensured while data analysis was crossed in order to identify the pattern and summarize findings from the research.

\section{Results}

The general background of the organization which were interviewed were summarized under several themes which include; the competitive environment in which they operate, the current carbon reduction practices across their supply chain, the drivers and variables of carbon efficiency, and most specifically, human factor whose significance has been underlined by several authors (KusiSarpong et al., 2019; Jabbour et al., 2015; Jabbouret al., 2019; Jabbour et al., 2008; de Sousa Jabbour et al., 2018; Renwick et al., 2013).

The findings on the significance of human factors towards the attainment of sustainable carbon efficiency in manufacturing is in line with the deductions of Renwick et al. (2013), Kusi-sarpong et al. (Kusi-Sarpong et al., 2019) and Jabbour et al. (Jabbour et al., 2015; Jabbouret al., 2019; Jabbour et al., 2008; de Sousa Jabbour et al., 2018). Jabbour et al. (Jabbouret al., 2019) highlighted several dimensions of human engagement which substantially determine the attainment of carbon reduction goals, this was tagged 'human side of organization' be it servicing, or manufacturing industry. Based on the questionnaires that were administered, the results of the survey are further highlighted below;

\subsection{Boundary of operation of the company}

According to Cholette \& Venkat (Cholette and Venkat, 2009) and Hua et al. (2011), the configuration of the SC of an organization shows a different demand for energy use and hence the rate of $\mathrm{CO}_{2}$ emissions, mostly based on its logistical and transport activities. The overview of the operational limit of the participants' organization shows that 21 respondents come from companies which operate locally, globally and regionally. Most of the participants (33.3\%) operate locally within their country.

\subsection{Description of participants}

Since this research is centred on the supply chain, the most appropriate personnel for answering questionnaires were the supply chain professionals (Hines, 2014; Christopher, 2016). Although the research required inputs from supply chain manager or environmental specialist, many organizations have different Job titles for these roles which are being revealed in Fig. 1. The individual participants represent its company. The views of Environmentalist were also considered in this study.

\subsection{Scope of carbon reduction in the business formulation}

The percentage of participants that has the carbon reduction as part of their business strategy signifies a higher portion of companies $(81 \%)$ that filled the questionnaire. This shows awareness about the relevance of incorporating carbon reduction strategies into business strategy.

\subsection{Perspective on carbon emission auditing}

Auditing of carbon emissions is important in identifying opportunities for reduction. Fig. 2 shows that 13 out of 21 respondents representing $70 \%$ realised the relevance of carbon emission auditing to their business operations and 20\% find it immaterial. Also, three respondents from the companies who have not applied carbon efficiency in their strategy concluded that it is immaterial. When comparing a service SC with a manufacturing SC, the emissions from the former are often minimal and mostly have their emissions from office utilities like lighting and from suppliers (upstream players) who deliver office stationeries (Uyarra et al., 2014). Another key observation is that two companies who had implemented carbon efficiency in their strategy do not see carbon emissions auditing as relevant.

\subsection{Drivers of carbon efficient supply chain}

The drivers for energy consumption and carbon efficiency identified by the participant are highlighted as follows; Electricity bill and energy prices, cost savings from energy savings,

Table 1

Interviews conducted in case study company.

\begin{tabular}{|c|c|c|c|c|}
\hline Company & Interviewees Job role & Number for each role. & Total number interviewed & Duration \\
\hline Damco & Green logistics manager & 1 & 1 & $45 \mathrm{mins}$ \\
\hline \multirow[t]{2}{*}{ y (gamma) } & Sustainable purchase manager & 4 & 7 & $20 \mathrm{mins}$ \\
\hline & Environmental manager & 3 & & Email interview \\
\hline \multirow[t]{4}{*}{$\delta$ (delta) } & System manager & 1 & 7 & Email interview \\
\hline & Environmental advisor & 2 & & 15 mins \\
\hline & Environmental advisor & 2 & & Email interview \\
\hline & Environmental advisor & 2 & & Email interview \\
\hline \multirow[t]{3}{*}{ Z (zeta). } & Carbon reduction advisor & 2 & 6 & $15 \mathrm{mins}$ \\
\hline & Carbon reduction advisor & 3 & & Email interview \\
\hline & Corporate contract office & 1 & & Email interview \\
\hline
\end{tabular}


Table 2

Brief description of the investigated manufacturing companies.

\begin{tabular}{|c|c|c|}
\hline Themes & Interviewees' manufacturing organization & \\
\hline Introduction & $\begin{array}{l}\delta \text { (delta) } \\
\text { The company is among the top ten car } \\
\text { manufacturer in Europe as at } 2018 \text { in term of } \\
\text { quantity sold and the revenue earned. They } \\
\text { have received several international awards and } \\
\text { was ranked the second carbon efficient } \\
\text { automobile manufacturer. They are the first } \\
\text { company to put up electric passenger cars for } \\
\text { sale. The company is focused on becoming the } \\
\text { major industrial player in low carbon vehicle } \\
\text { manufacturing with considerations given to the } \\
\text { environmental legislative standards under } \\
\text { Europe Union Emissions Trading Systems } \\
\text { (EUETS). }\end{array}$ & $\begin{array}{l}\mathrm{Z} \text { (zeta). } \\
\text { Unlike the other two companies, Zeta is } \\
\text { a public sector company mainly dealing } \\
\text { with service provision which include; } \\
\text { fire and public safety, transport and } \\
\text { highways management. } \\
\text { They have quantified their carbon } \\
\text { emission contribution and has } \\
\text { developed carbon emission reduction } \\
\text { plan. They have also come up with } \\
\text { "Zero carbon" initiative which is } \\
\text { intended to reduce their carbon } \\
\text { footprints. }\end{array}$ \\
\hline
\end{tabular}

y (gamma)

The company is among the "Big 3" car

manufacturing companies in the globe. Globally, the company produces under two brand nomenclature with various car model. Both brands are focusing on the design of compact products while developing outstanding experiences for their customer with environment-friendly inventions in the form of superb and fast-moving automobiles. The company incorporates social and environmental responsibility into its business to determine better ways towards sustainable products and manufacturing. The company considers the differences in environmental legislative standards (EUETS, US regulations) when comparing the emerging markets to established markets. analysis

Current practices

Drivers of carbon efficiency

The company has set an environmental responsibility goals which is hoped to the turnover and market acceptance.
Competitive environment
They compete in a market with other companies like Volkswagen, Daimler, and the logistic cost through the localization of manufacturing of cars. The company focus on adapting products to customer expectation taking cognizance of technological and energy shift in order to achieve cost advantage over the competitors. They are competing in term of low carbon commercial vehicle manufacturing.

The company has applied environmental management system based on ISO 14001 standard. Also, the company reduces its emissions from supplier end by setting emission targets for them and also by localizing the manufacturing of parts.
They are using energy efficient appliances across most of their operations. Also, they promote waste recycling, while sourcing consumables locally. They have also employed renewable energy technology such as solar PV to reduce carbon emissions. With regards to the supply chain management, the organization has carbon efficient procurement policy and has included this as a part of tender process for the potential suppliers The major driver is the awareness of the overall consequences of increasing carbon footprint which may lead to budget shrinkage for critical infrastructures.
They compete in a market with other automobile manufacturers like Daimler, Mercedes Benz, and Volkswagen, which are the topmost brands in exquisite cars and engines manufacturing. They face competition in the market for alternative technology engines like the hybrid engines; hydrogen-powered engines, diesel engines. In the UK market, there are threats from consumers who decide to save on the energy (fuel) that could have been consumed or emissions emitted from the use of cars.

The company applies the "Environmental innovation" to progress to "lower-carbon world" across the product lifecycle. The company engages multiple approaches to enhance the vehicles performance with a high focus on its end-use emissions, also called "vehicle tailpipe $\mathrm{CO}_{2}$ emissions". Also, the company cuts its emissions from supplier end by setting targets toward meeting ISO 14001 standard.
The group applies "Integrated business strategy, centred on environmental innovation which takes into considers various environmental legislative standards, proactive approach, lifecycle approach, setting targets for suppliers, alignment of purchasing strategy with environmental innovation goals, incorporation of $\mathrm{CO}_{2}$ emissions in sourcing process, cost is an internal driver, reputation risk" is an external driver.

One of the respondents asserted that "In terms of competitiveness, we are have gone far enough on the journey to be able to comment on the benefits"; but so far, the company has experienced benefits regarding cost savings. Rgarding innovation, the respondent confessed that "quantifying carbon impact gives transparency to the supply chain, which then enables innovative thinking for carbon footprint reduction". Lastly, the respondents asserted that "Integrating responsible business practices into the core of the business and driving continuous improvement regarding the environmental protection, advance our reputation and adds to our brand value."

Human factors in carbon efficiency
They identified human factor at all level of their Human factor has been identified, and production and recognize them as a major factor toward low carbon vehicles production. attention shifted to behavioral campaign such as resource management training and smarter driving training. 


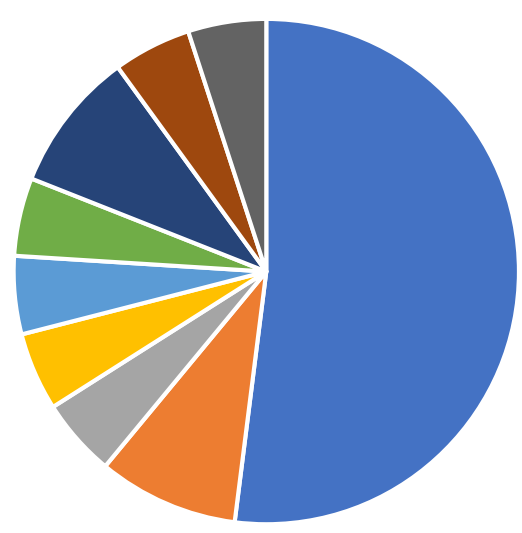

- Supply chain
Professionals
- Logistics managers
- Operations managers
- Site managers
- Procurement Manager
- Innovations Director
- Environmental managers
- Strategy Director
- Customer Order Manager

Fig. 1. Job descriptions of the participant.

Government regulations and taxes, Investors, consumers, the risk associated with climate change, opportunities, and collaboration with suppliers. Also, one of the participants posited that total commitment from the business to reduce carbon emissions landfill and energy usage is a driver. This additional information explains the importance of being involved from the management and putting in place a monitoring tool for measuring carbon emission compliance progress. The comment justifies the use of ISO 14001 (which is a well-known environmental standard) as a tool for ensuring environmental compliance (Delmas, 2001; Babakri et al., 2003).

\subsection{Barriers to carbon reduction strategy implementation}

As per the carbon reduction implementation strategies, Fig. 3 shows that $56 \%$ of the respondents had a "No" which signifies that they had a successful implementation. The "Yes" responses provided reasons ranging from the complexity of the supply chain as they have to "imports from the Far East and China", which is quite a distance apart. This type of barrier could be due to differences in regulation for China and the destination of delivery which often makes it difficult for supply chain emissions data to be tracked. However, with the advent of the Internet of things (IoT), it is feasible to track the emission through a possibility of exchanging information between the manufacturer, operator, and supply chain across the globe (Tao et al., 2014; Vermesan et al., 2011; GuerreroIbanez et al., 2015; Sarkar et al., 2018; Bandyopadhyay and Sen, 2011). Another barrier identified was in the area of product distribution, as they tend to use "more trucks than needed based on their customers request for pallets for the individual products which tend to consume space, hence requiring the use of more truck" (emission sources) Fig. 4

Increase use of trucks implies more emission which the company may not be able to control due to the packaging of pallets with the product requested by customers since the use of freight transport, especially road transport, has been identified as a very high emitter of $\mathrm{CO}_{2}$ (Dekker et al., 2012; Lewis et al., 2017; Hoffertet al., 2002; McKinnon et al., 2015). It can be concluded that the responder's company has experienced barrier, given that the customers are the ultimate in the supply chain since all the products and services are ultimately delivered to satisfy them.

\subsection{Variables of competitive carbon efficient supply chain}

The benefits that can be gained from implementing carbon reduction strategies in manufacturing goes beyond cost saving, which is often the most cited benefit in literature. Other benefits identified by the participants include; Innovation of products and processes, Improvement in Corporate social responsibility reputation, Improvement in brand value, Increased market share, Improvement in supply chain efficiency, Investors' attraction, redesign for supply chain efficiency. The respondents were further asked if they will consider reducing their emission during the recession. This was done to measure the extent to which the companies have identified the benefits. According to Hopkins et al.

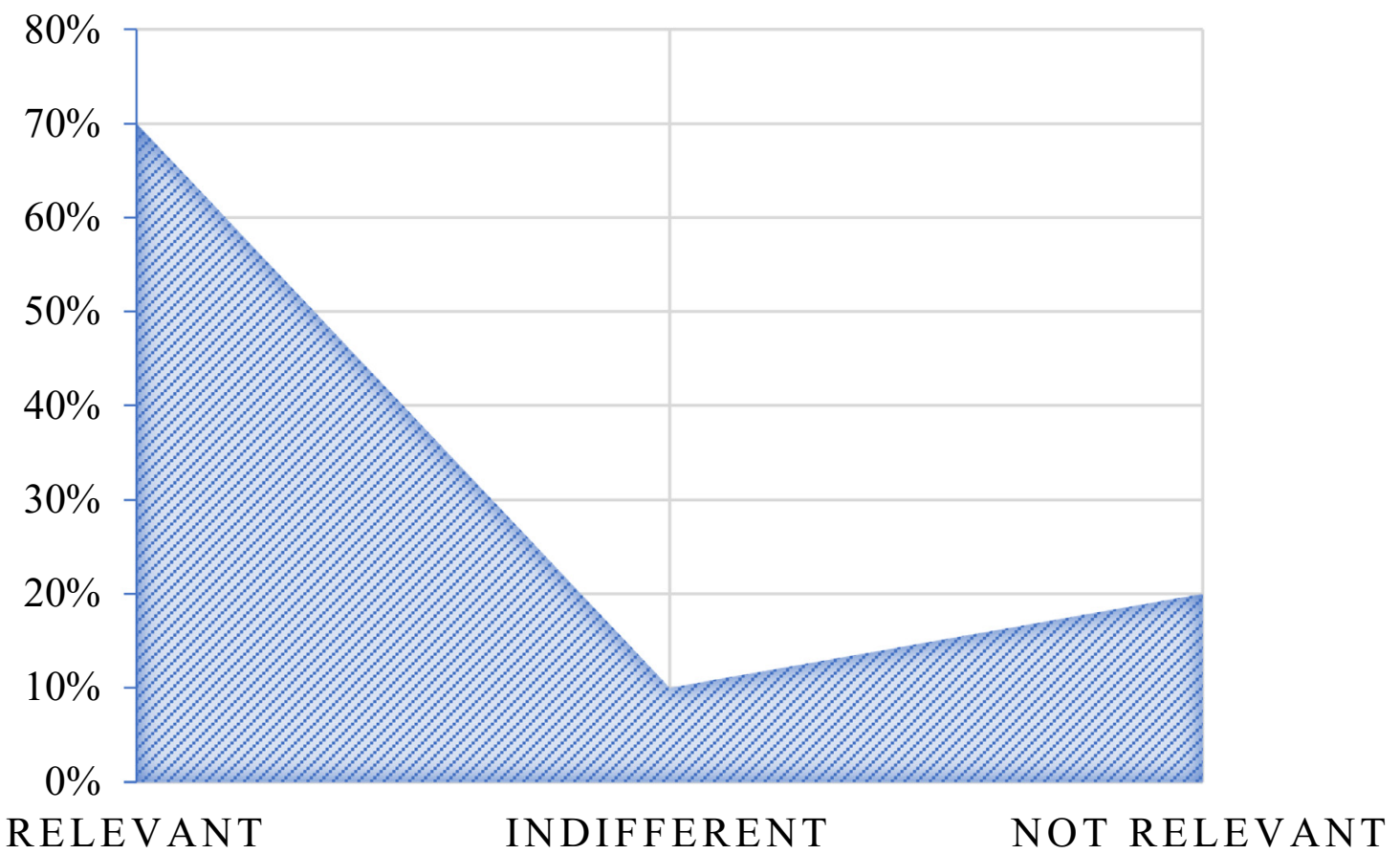

Fig. 2. Company perspective on carbon emission auditing. 


\section{$\square$ Yes $\quad$ No $\quad$ Not applicable}

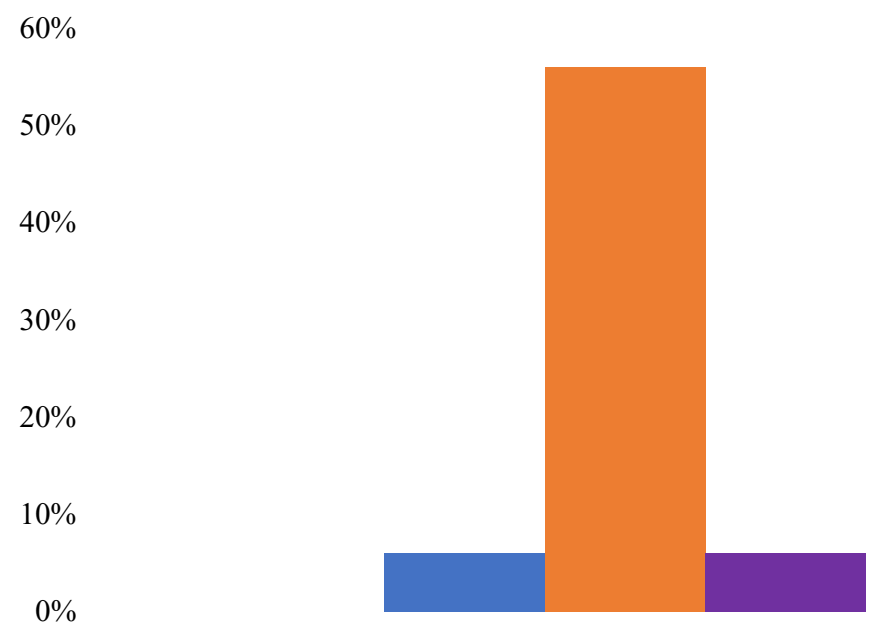

Fig. 3. Are there any barrier to carbon reduction strategies?.

(2011), the economic downturn may lead some companies to neglect actions on sustainability, but the companies that have identified the opportunities will continue to invest. From the survey, 16 participants agreed to reduce their emission during the recession, 5 do not agree. Also,11 respondents agreed that customers are concerned about their carbon footprints while 5 each do not know or agree.

\subsection{Basis of competition}

It is evident from Fig. 4 that $66.7 \%$ agree to being able to compete based on carbon efficient supply chain. This signifies that many organizations are aware of the benefits of the integration of carbon efficiency along their supply chain.

\subsection{Carbon efficiency and cost savings}

The Fig. 5 shows that the highest percentile distribution which is $66.67 \%$ of 21 respondent agreed that there is an increase in cost savings when a supply chain is made more carbon efficient. 9 out of 17 strategically aligned company see an increase in innovation. However, 5 of 17 respondents realised the impact on their customer service.

Although not many literature identify the link between these two factors, Wright et al. (2009) established that there is an equilibrium between cost-effectiveness, and customer service consequent upon carbon efficiency since the minimization of carbon emission is in tandem with waste reduction which leads to improved quality. A proportion of 10 out of 21 attests to an improvement in quality. A cross-analysis shows that majority (8 out of 17) of the companies see an increase in "Added value" of their product or service when carbon reduction strategies are implemented in their supply chain. This is in tandem with what has been proved by researchers (Lee, 2011; ACTION(CDP), 2018; Jabbour et al., 2015). It should be noted that it is not only carbon reduction alignment that is responsible for cost saving but much can be achieved when an organization is strategically aligned (Lee and Cheong, 2011).

\subsection{Model for the implementation of efficient carbon strategies along the supply chain}

In view of the survey which was carried out, the best practice flowchart was designed as shown in Fig. 6. Assessment of the value chain emission was identified as the starting point for the development of goals and targets. The mitigating strategies are highly influenced by the risk associated with non-implementation. One key input which has been shown in the model developed is the use of metrics. This was supported by one of the respondents to the questionnaires who attested to the need for the development of indicators or metrics within the company to ensure proper implementation. Although, the model may not have been followed in its depicted order, the relevance of different stages was identified from the research based on the questionnaire responses. This confirms that this model can be adopted by the manufacturing organization if they take into consideration the needed steps to stay ahead of the market competitors. The drivers who have been provided earlier need to be in place for a manufacturing company to achieve its desired outcome from the implementation of the model. This can be justified by authors from applicable literature which

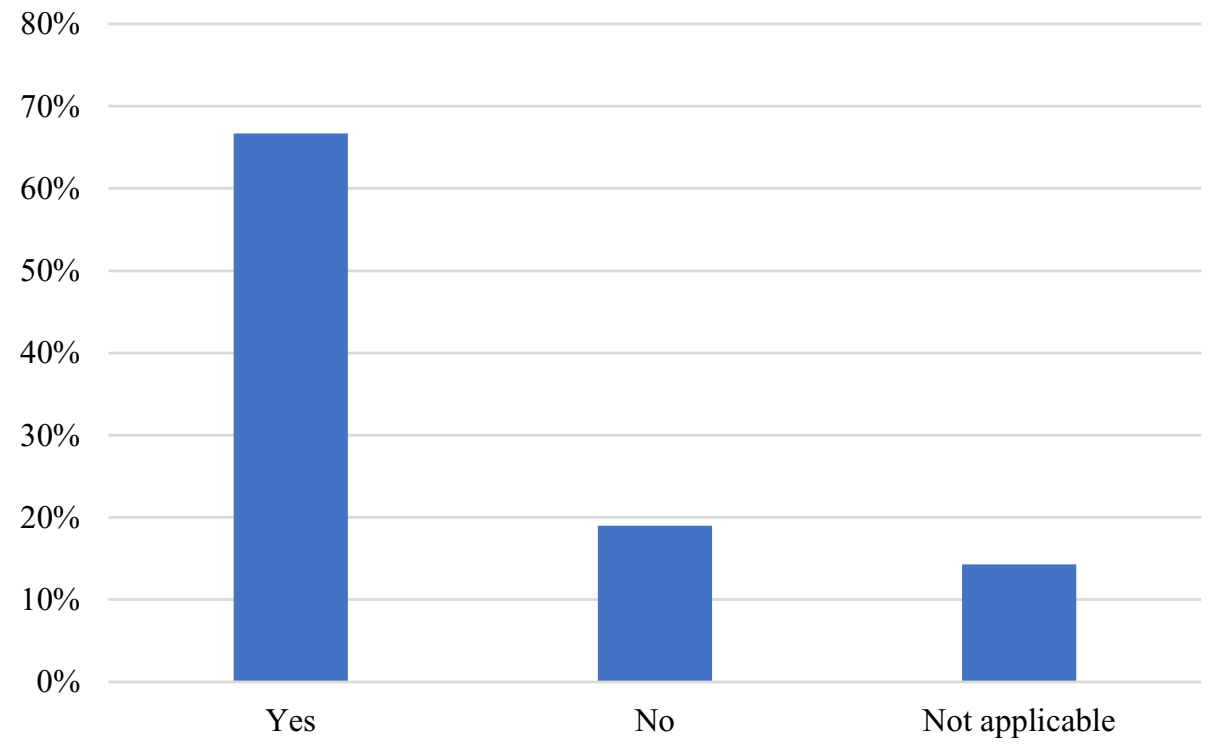

Fig. 4. Would you compete based on a carbon efficient SC?. 


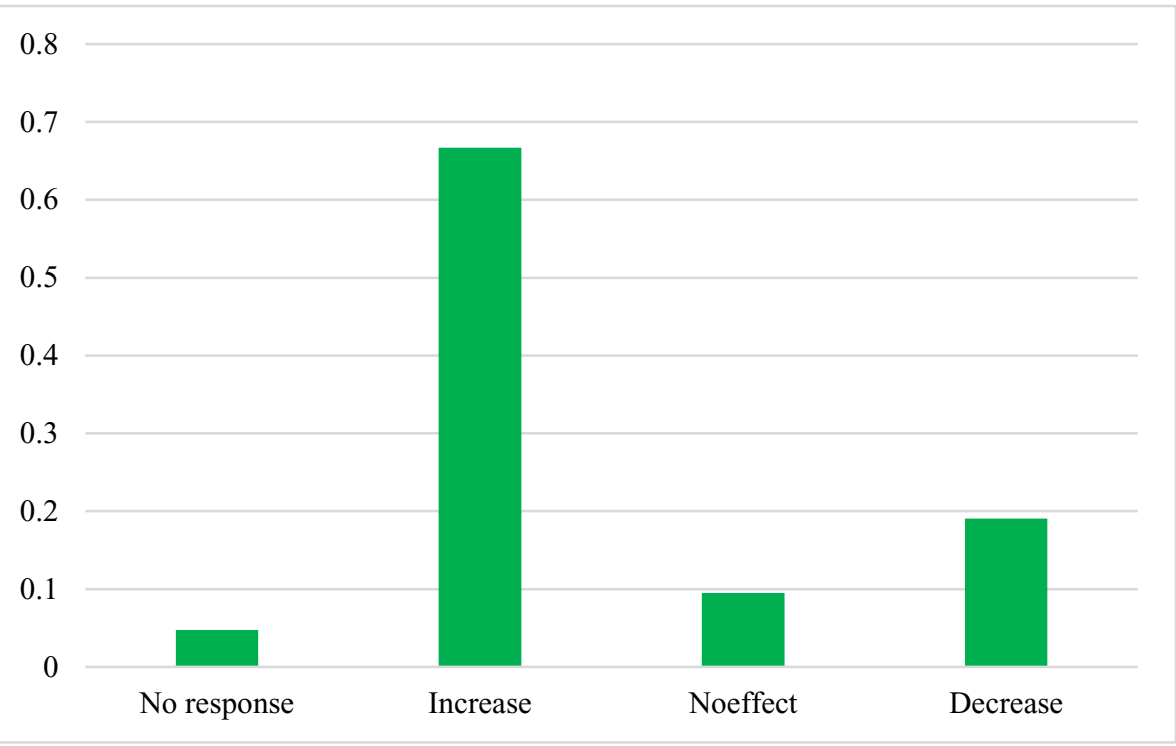

Fig. 5. Impact of carbon efficiency on cost saving.

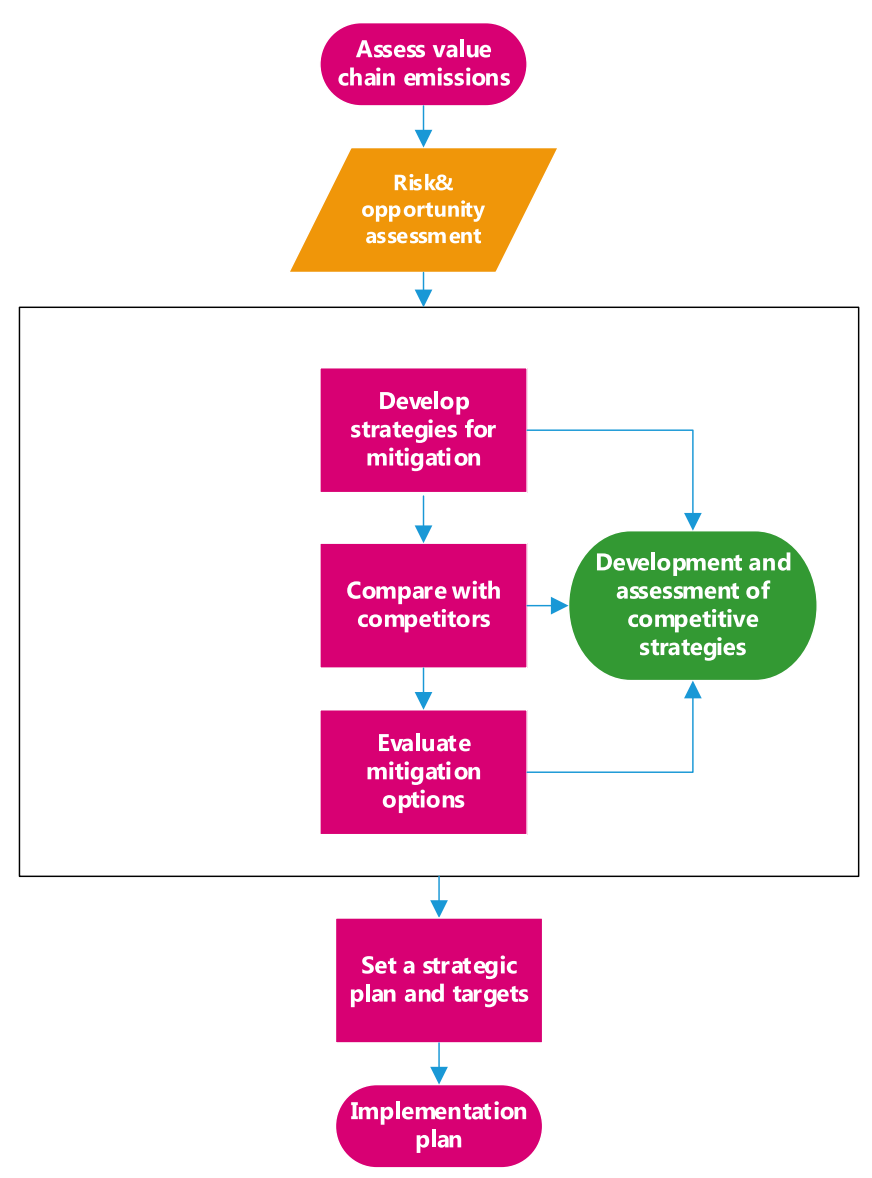

Fig. 6. A Strategic model for implementation of Carbon efficient strategies along the SC.

have suggested these stages (Hua et al., 2011; Benjaafar et al., 2013; HoffmanTang and Yeoh, 2007; Schultz and Williamson, 2006; Stone and Ozimek, 2011).

\section{Strategies toward the attainment of competitive advantages in carbon emission reduction}

The research article offers the following operational strategies to mitigate the carbon emissions throughout the lifespan of manufactured products in order to derive maximum benefits and enhance competitive advantage. These are discussed as follow:

II. Intelligent monitoring of carbon emission along the supply chain-The application of artificial intelligent tool will reduced what Jabbour et al. (Jabbouret al., 2019) called 'human side of organization' which underline several dimensions of human engagement in the course of product manufacturing. What this means is that the monitoring process is automated, this will to some extent reduce the compromising human influence on the process. The intelligent model will include real-time carbon emission threshold monitoring.

III. Application of green practices model-The green practice model which was proposed by (Sellitto et al., 2019) based on 21 green practices related to green supply chain management could be very useful towards the attainment of carbon reduction in the automobile industries. The 21 green practices were clustered into four categories namely; innovation at all level of product development, collaboration of similar manufacturing organization on carbon footprint reduction, operation and mitigation (Sellitto et al., 2019). Automobile manufacturing organization can classify their carbon emission reduction strategies into these four categories while identifying the related practices under each category. This can serve as a metrics to measure the level of compliance and the progress made towards green manufacturing.

IV. Consumer education and awareness strategies- Since it has been agreed that consumer is a major player in attaining competitive advantage in carbon emission reduction, there is a need for proper dissemination of information about the carbon reduction strategies which are currently applied in the automobile manufacturing industries. This may be included in product information package or as part of a paid advert.

V. Compliance-based appraisal- Since human has been identified as a critical stakeholder in carbon footprint reduction, personnel appraisal should include carbon emission compliance. Also, there should be a deterrent and incentive system which either punish or reward the compliance at all levels of the supply chain. 
These will further trigger different supplier to take the issue of carbon reduction with utmost seriousness. A deliberate effort should be applied to expel non-compliance supplier along the supply chain system.

\section{Conclusion}

This article investigates the competitive advantage of a carbon efficient supply chain with the consumer as the primary driver while identifying the impact of other existing strategic factors. Some automobile manufacturing company in the United Kingdom were considered as the case study. Different drivers and barrier in the attainment of carbon efficient supply chain in the manufacturing industry were identified while the operation strategies for the attainment of competitive advantage in carbon emission reduction were proposed. Since competitive advantage evolves from the array of activities carried out in the supply chain, then the carbon reduction strategy should be implemented in such a way that it aligns with these activities. The choice of strategy for reducing emissions should be tailored to the needs of the supply chain offering the appropriate balance between the strategic factor important to the supply chain and the carbon reduction goals. In overall, different level of motivation for carbon footprint reduction were identified among the investigated industries. As future research, intelligent model for manufacturing supply chain carbon threshold monitoring will be developed and tested based on different supply chain scenarios.

\section{Author contributions}

Conceptualization, O.O and O.A.; Data curation, O.A.; Formal analysis, O.O., O.A and P.A; Investigation, O.O O.A and F.I.; Project administration, O.A and F.I.; Validation, N.M and S.A.A.; Visualization, F.I.; Writing—original draft, O.O.; Writing—review \& editing, O.O., O.A., P.A., N.M and S.A.A.

\section{Conflicts of interest}

\section{Authors declare no conflict of interest.}

\section{References}

ACTION(CDP), D.I.. Closing the Gap: scaling up sustainable supply chains. https:// 6fefcbb86e61af1b2fc4-c70d8ead6ced550b4d987d7c03fcdd1d.ssl.cf3.rackcdn. $\mathrm{com} / \mathrm{cms} /$ reports/documents/000/003/014/original/CDP_Supply_Chain_ Report_2018.pdf?1518084325. (Accessed 22 August 2018).

AFRICA, A., 2009. SOUTHERN AFRICAN POULTRY ASSOCIATION CONGRESS AND EXPO (AVI/SAPA). In: Annual Reports of the Egg, Chick and Broiler Industries of Southern African Poultry Association. Avi Africa Conference Brochure, 2009, pp. 19-53.

Agi, M.A., Nishant, R., 2017. Understanding influential factors on implementing green supply chain management practices: an interpretive structural modelling analysis. J. Environ. Manag. 188, 351-363.

Ambekar, S., Prakash, A., Patyal, V.S., 2019. Role of culture in low carbon supply chain capabilities. J. Manuf. Technol. Manag. 30 (1), 146-179.

Babakri, K.A., Bennett, R.A., Franchetti, M., 2003. Critical factors for implementing ISO 14001 standard in United States industrial companies. J. Clean. Prod. 11 (7), $749-752$.

Bandyopadhyay, D., Sen, J., 2011. Internet of things: applications and challenges in technology and standardization. Wirel. Pers. Commun. 58 (1), 49-69.

Bell, E., Bryman, A., Harley, B., 2018. Business Research Methods. Oxford university press.

Benjaafar, S., Li, Y., Daskin, M., 2013. Carbon footprint and the management of supply chains: insights from simple models. IEEE Trans. Autom. Sci. Eng. 10 (1), 99-116.

Carlton, D.W., Perloff, J.M., 2015. Modern Industrial Organization. Pearson Higher Ed.

Centobelli, P., Cerchione, R., Esposito, E., 2018. Environmental sustainability and energy-efficient supply chain management: a review of research trends and proposed guidelines. Energies 11 (2), 275.

Chatterjee, K., Pamucar, D., Zavadskas, E.K., 2018. Evaluating the performance of suppliers based on using the R'AMATEL-MAIRCA method for green supply chain implementation in electronics industry. J. Clean. Prod. 184, 101-129.

Cholette, S., Venkat, K., 2009. The energy and carbon intensity of wine distribution: a study of logistical options for delivering wine to consumers. J. Clean. Prod. 17 (16), 1401-1413.

Christopher, M., 2016. Logistics \& Supply Chain Management. Pearson UK.

Dasaklis, T.K., Pappis, C.P., 2013. Supply chain management in view of climate change: an overview of possible impacts and the road ahead. J. Ind. Eng. Manag. $6(4), 1124-1138$.

de Sousa Jabbour, A.B.L., Chiappetta Jabbour, C.J., Sarkis, J., Gunasekaran, A., Furlan Matos Alves, M.W., Ribeiro, D.A., 2018. Decarbonisation of operations management-looking back, moving forward: a review and implications for the production research community. Int. J. Prod. Res. 1-23.

Dekker, R., Bloemhof, J., Mallidis, I., 2012. Operations Research for green logistics-An overview of aspects, issues, contributions and challenges. Eur. J. Oper. Res. 219 (3), 671-679.

Delmas, M., 2001. Stakeholders and competitive advantage: the case of ISO 14001. Prod. Oper. Manag. 10 (3), 343-358.

Fereday, J., Muir-Cochrane, E., 2006. Demonstrating rigor using thematic analysis: a hybrid approach of inductive and deductive coding and theme development. Int. J. Qual. Methods 5 (1), 80-92.

Garen, K., 2009. Late adopters run the risk of being left to flounder. CPA J. 79 (5), 17.

Goel, A., Ganesh, L., Kaur, A., 2019. Deductive content analysis of research on sustainable construction in India: current progress and future directions. J. Clean. Prod. 226, 142-158.

Guerrero-Ibanez, J.A., Zeadally, S., Contreras-Castillo, J., 2015. Integration challenges of intelligent transportation systems with connected vehicle, cloud computing, and internet of things technologies. IEEE Wirel. Commun. 22 (6), 122-128.

Hertwich, E.G., Peters, G.P., 2009. Carbon footprint of nations: a global, trade-linked analysis. Environ. Sci. Technol. 43 (16), 6414-6420.

Hines, T., 2014. Supply Chain Strategies: Demand Driven and Customer Focused. Routledge.

Hoffert, M.I., et al., 2002. Advanced technology paths to global climate stability: energy for a greenhouse planet. Science 298 (5595), 981-987.

Hoffman, A.J., Tang, K., Yeoh, 2007. The coming market shift: business strategy and climate change.

Hopkins, M.S., Haanaes, K., Balagopal, B., Velken, I., Kruschwitz, N., Arthur, D., 2011. New sustainability study: the embracers seize advantage. MIT Sloan Manag. Rev. 52 (3), 23.

Hua, G., Cheng, T., Wang, S., 2011. Managing carbon footprints in inventory management. Int. J. Prod. Econ. 132 (2), 178-185.

Jabbour, C.J.C., Santos, F.C.A., Nagano, M.S., 2008. Environmental management system and human resource practices: is there a link between them in four Brazilian companies? J. Clean. Prod. 16 (17), 1922-1925.

Jabbour, C.J.C., Neto, A.S., Gobbo Jr., J.A., de Souza Ribeiro, M., de Sousa Jabbour, A.B.L., 2015. Eco-innovations in more sustainable supply chains for a low-carbon economy: a multiple case study of human critical success factors in Brazilian leading companies. Int. J. Prod. Econ. 164, 245-257.

Jabbour, C.J.C., et al., 2019. Who is in charge? A review and a research agenda on the 'human side'of the circular economy. J. Clean. Prod. 222, 793-801.

Kusi-Sarpong, S., Gupta, H., Sarkis, J., 2019. A supply chain sustainability innovation framework and evaluation methodology. Int. J. Prod. Res. 57 (7), 1990-2008.

Lee, K.-H., 2011. Integrating carbon footprint into supply chain management: the case of Hyundai Motor Company (HMC) in the automobile industry. J. Clean. Prod. 19 (11), 1216-1223.

Lee, K.-H., Cheong, I.-M., 2011. Measuring a carbon footprint and environmental practice: the case of Hyundai Motors Co.(HMC). Ind. Manag. Data Syst. 111 (6), 961-978.

Lee, Y., et al., 2013. Production and characterization of biochar from various biomass materials by slow pyrolysis. Tech. Bull. J. Food Fert. Technol. Cent. 197, 1-11.

Lewis, H., Gertsakis, J., Grant, T., Morelli, N., Sweatman, A., 2017. Design+ Environment: a Global Guide to Designing Greener Goods. Routledge.

Malviya, R.K., Kant, R., Gupta, A.D., 2018. Evaluation and selection of sustainable strategy for green supply chain management implementation. Bus. Strateg. Environ. 27 (4), 475-502.

McKinnon, A., Browne, M., Whiteing, A., Piecyk, M., 2015. Green Logistics: Improving the Environmental Sustainability of Logistics. Kogan Page Publishers.

Morse, J.M., 2003. Principles of mixed methods and multimethod research design. In: Handbook of Mixed Methods in Social and Behavioral Research, vol. 1, pp. 189-208.

Penz, E., Polsa, P., 2018. How do companies reduce their carbon footprint and how do they communicate these measures to stakeholders? J. Clean. Prod. 195, $1125-1138$.

Petljak, K., Zulauf, K., Štulec, I., Seuring, S., Wagner, R., 2018. Green supply chain management in food retailing: survey-based evidence in Croatia. Supply Chain Manag.: Int. J. 23 (1), 1-15.

Plassmann, K., 2018. Comparing voluntary sustainability initiatives and product carbon footprinting in the food sector, with a particular focus on environmental impacts and developing countries. Dev. Policy Rev. 36 (4), 503-523.

Renwick, D.W., Redman, T., Maguire, S., 2013. Green human resource management: a review and research agenda. Int. J. Manag. Rev. 15 (1), 1-14.

Sarkar, S., Chatterjee, S., Misra, S., 2018. Assessment of the suitability of fog computing in the context of internet of things. IEEE Trans. Cloud Comput. 6 (1), $46-59$.

Saunders, M.N., 2011. Research Methods for Business Students. Pearson Education India, $5 /$ e. 
Saunders, M., Lewis, P., Thornhill, A., 2007. Research Methods," Business Students, fourth ed. Pearson Education Limited, England.

Schultz, K., Williamson, P., 2006. Gaining competitive advantage in a carbonconstrained world: strategies for European business. Manag. Innov. Change 9.

Sellitto, M.A., Hermann, F.F., Blezs Jr., A.E., Barbosa-Póvoa, A.P., 2019. Describing an organizing green practices in the context of green supply chain management: case studies. Resour. Conserv. Recycl. 145, 1-10.

Seman, N.A.A., Zakuan, N., Jusoh, A., Arif, M.S.M., Saman, M.Z.M., 2012. Green supply chain management: a review and research direction. Int. J. Manag. Val. Supply Chains 3 (1), 1-18.

Silins, N., 2009. LEED \& the safety profession. Prof. Saf. 54 (3), 46.

Skillman, M., Cross-Barnet, C., Friedman Singer, R., Rotondo, C., Ruiz, S., Moiduddin, A., 2019. A framework for rigorous qualitative research as component of mixed method rapid-cycle evaluation. Qual. Health Res. 29 (2), 279-289.

Smith, E.E., Perks, S., 2010. A perceptual study of the impact of green practice implementation on the business functions. South. Afr. Bus. Rev. 14 (3).

Stone, M., Ozimek, J., 2011. Corporate Carbon Strategies: Threats and Opportunities Arising from the New Energy Imperative. Business Insights Limited.

Sun, J., Zhu, Q., 2018. Organizational green supply chain management capability assessment: a hybrid group decision making model application. IEEE Eng. Manag. Rev. 46 (1), 117-127.

Sundarakani, B., Goh, M., de Souza, R., Shun, C., 2008. Measuring Carbon Footprints across the Supply Chain.

Takefuji, Y., Yamada, R., 2019. A New Deductive Method with Intelligence Using Pseudorandom Number for Solving Coin-Weighing Puzzles: Review of Inductive and Deductive Methods.
Talaei, M., Moghaddam, B.F., Pishvaee, M.S., Bozorgi-Amiri, A., Gholamnejad, S., 2016. A robust fuzzy optimization model for carbon-efficient closed-loop supply chain network design problem: a numerical illustration in electronics industry. J. Clean. Prod. 113, 662-673.

Tao, F., Zuo, Y., Da Xu, L., Lv, L., Zhang, L., 2014. Internet of things and BOM-based life cycle assessment of energy-saving and emission-reduction of products. IEEE Trans. Ind. Inf. 10 (2), 1252-1261.

Tiwari, M.K., Chang, P.-C., Choudhary, A., 2015. Carbon-efficient production, supply chains and logistics. Int. J. Prod. Econ. (164), 193-196.

Uyarra, E., Edler, J., Gee, S., Georghiou, L., Yeow, J., 2014. UK: UK public procurement of innovation: the UK case. In: Public Procurement, Innovation and Policy: International Perspectives, pp. 233-257.

Vermesan, O., Friess, P., Friess, P., 2011. Internet of Things: Global Technological and Societal Trends. River Publishers Aalborg, Denmark.

Voss, C., 2010. Case research in operations management. In: Researching Operations Management. Routledge, pp. 176-209.

Vreys, K., Lizin, S., Van Dael, M., Tharakan, J., Malina, R., 2019. Exploring the future of carbon capture and utilisation by combining an international Delphi study with local scenario development. Resour. Conserv. Recycl. 146, 484-501.

Walliman, N., 2017. Research Methods: the Basics. Routledge.

Wilkerson, T., 2005. Can One Green Deliver Another. Harvard Business School Publishing Corporation. See. http://www.supply.chain.strategy.org.

Wright, J., Jones, D., Hoyle, S., 2009. The Sustainable Supply Chain. Accenture.

Yin, R., 2009. Case study h researc design and methods fourth edition. Appl. Soc. Res. Methods Ser. 5.

Yin, R.K., 2015. Estudo de Caso-: Planejamento e Métodos. Bookman editora. 